\title{
Telisik Determinan Kinerja Karyawan
}

\author{
Anies Khaqul Yaqinah, Aprih Santoso \\ Fakultas Ekonomi Universitas Semarang \\ Email: aprihsantoso@usm.co.id
}

Naskah diterima 24 Maret 2020, Revisi 30 Maret 2020, Terbit 19 April 2020

\begin{abstract}
Abstrak
DOI: doi.org/10.21107/pamator.v13i1.6952

Permasalahan dalam penelitian ini dimana karyawan telemarketing Bank Sinar Mas Cabang Semarang tidak mampu mencapai target yang telah ditetapkan oleh Bank Sinar Mas Cabang Semarang dan penelitian ini bertujuan untuk menganalisis faktor etos kerja, keterampilan, kompetensi dan komunikasi terhadap terhadap kinerja karyawan telemarketing Bank Sinar Mas Cabang Semarang. Populasi dalam penelitian ini adalah seluruh karyawan telemarketing Bank SinarMas Cabang Semarang yang berjumlah 66 karyawan sedangkan teknik sampling yang digunakan adalah teknik sensus dan alat analisis yang digunakan dalam penelitian ini regresi linier berganda. Hasil penelitian menunjukkan bahwa variabel etos kerja, keterampilan, kompetensi dan komunikasi berpengaruh positif dan signifikan terhadap kinerja karyawan telemarketing Bank Sinar Mas Cabang Semarang serta hasil nilai adjusted R-square pada model regresi diperoleh sebesar 0,551 yang artinya 55,1 persen variabel kinerja karyawan dapat dijelaskan oleh variabel etos kerja, keterampilan, kompetensi dan komunikasi sedangkan sisanya sebesar 44,9 persen dijelaskan oleh variabel lain diluar penelitian ini.
\end{abstract}

Kata Kunci : etos kerja, keterampilan, kompetensi, komunikasi, kinerja karyawan

\begin{abstract}
The problem in this research is that the Semarang Branch Mas telemarketing employees were unable to achieve the targets set by the Semarang Branch Sinar Mas Bank and this study aimed to analyze the factors of work ethic, skills, competence and communication towards the performance of telemarketing employees of Bank Sinar Mas Semarang Branch The population in this study were all employees of the Semarang Branch SinarMas telemarketing, amounting to 66 employees while the sampling technique used was census technique and the analysis tool used in this study was multiple linear regression. The results showed that the work ethic, skills, competencies and communication variables had a positive and significant effect on the performance of the employees of Bank Sinar Mas Semarang Branch telemarketing and the results of the adjusted $R$ square value in the regression model were obtained at 0.551 which means 55.1 percent of employee performance variables can be explained by work ethic, skills, competence and communication variables while the remaining 44.9 percent is explained by other variables outside of this study.
\end{abstract}

Keywords : work ethic, skills, competence, communication

\section{PENDAHULUAN}

Sumber daya manusia merupakan sumber daya terpenting dalam suatu organisasi dimana orang-orang yang ada di dalamnya mencurahkan tenaga, bakat, kreativitas, dan usaha mereka kepada organisasi. Oleh karena itu, manusia merupakan salah satu faktor penentu keberhasilan dalam suatu organisasi karena manusia memberikan kontribusi terbesar dibandingkan dengan faktor-faktor yang lain. Untuk mendapatkan tenaga kerja yang cakap maka perusahaan harus mengadakan penarikan karyawan secara selektif agar sesuai dengan job description dan job specification.
Kinerja merupakan suatu kondisi yang harus dketahui yang harus dikonfirmasikan kepada pihak tertentu untuk mengetahui tingkat pencapaan hasil suatu instansi dihubungkan dengan suatu visi dan diemban suatu organisasi atau perusahaan yang serta mengetahui dampak positif dan negatif dari suatu kebijakan operasional (Robbins, 2010). Konsep kinerja banyak menghiasi kajian dan praktek dibidang manajemen, sebagai salah satu konsep vital yang menentukan gerak dan perkembangan dari manajemen tertentu.

Amstrong (2012) menyatakan kinerja adalah tentang melakukan pekerjaan dan hasil yang dicapai dari pekerjaan tersebut. 
Kinerja merupakan hasil pekerjaan yang mempunyai hubungan kuat dengan tujuan strategis organisasi, kepuasan dan memberikan kontribusi ekonomi. John (2010) menyatakan kinerja adalah pelaksanaan fungsi-fungsi yang dituntun dari seseorang atau suatu perbuatan, suatu prestasi, suatu pameran umum keterampilan.

Peran yang sangat vital dalam mewujudkan prestasi kinerja seorang karyawan adalah dirinya sendiri. Anoraga (2010) berpendapat bahwa keberhasilan dalam persaingan kerja tidak hanya membutuhkan keahlian dan kemampuan saja tetapi juga diperlukan adanya dedikasi, kerja keras, dan kejujuran dalam bekerja. Seseorang yang berhasil harus memiliki pandangan dan sikap yang menghargai kerja sebagai sesuatu yang luhur untuk eksistensi manusia.Karyawan yang memiliki pemikiran yang luhur mengenai pekerjaannya dapat bekerja dengan tulus. Suatu pandangan dan sikap terhadap kerja dikenal dengan istilah etos kerja, etos kerja adalah sikap yang muncul atas kehendak dan kesadaran sendiri yang didasari oleh sistem orientasi nilai budaya terhadap kerja. Sukardewi (2013) dan Samosir (2016) melakukan penelititan dengan hasil etos kerja berpengaruh positif dan signifikan terhadap kinerja karyawan.

Insentif sebagai sarana motivasi yang mendorong para pegawai untuk bekerja dengan kemampuan yang optimal, yang dimaksudkan sebagai pendapatan ekstra di luar gaji atau upah yang telah ditentukan Menurut Hasibuan (2012) mengemukakan bahwa insentif adalah tambahan balas jasa yang diberikan kepada karyawan tertentu yang prestasinya di atas prestasi standar. Mangkunegara (2012) mengemukakan bahwa insentif adalah suatu bentuk motivasi yang dinyatakan dalam bentuk uang atas dasar kinerja yang tinggi dan juga merupakan rasa pengakuan dari pihak organisasi terhadap kinerja karyawan dan kontribusi terhadap organisasi (perusahaan) dan hasil penelitian Fath (2016) menunjukkan bahwa insentif berpengaruh positif dan signifikan terhadap kinerja karyawan.

Komunikasi mencakup hampir keseluruhan aspek dalam kehidupan, terutama dalam praktik keseharian sosial masyarakat yang memiliki bentuk dan kehidupan organisasi, dimana terdapat berbagai unsur komunikasi yang terjadi di dalamnya. Komunikasi dan organisasi memang terdiri dari dua konsep. Namun bisa dibilang keduanya sudah saling terkait satu sama lain dan tidak bisa untuk dipisahkan. Komunikasi memegang peranan penting dalam suatu organisasi dimana merupakan suatu proses sekaligus sarana untuk saling berbagi informasi antara para anggota atau pihak yang berada dalam organisasi (Robbins, 2012). Kreitner dan Kinicki (2005) menyatakan bahwa komunikasi merupakan pertukaran informasi antar pengirim dan penerima, dan kesimpulan (persepsi) makna antara individu-individu yang terlibat dan hasil Penelitian Sumaki dan Taroreh (2015) yang menghasilkan bahwa komunikasi berpengaruh positif dan signifikan terhadap kinerja karyawan.

Faktor lain yang mengakibatkan kinerja menurun adalah pengalaman kerja yang masih banyak belum dimiliki oleh para karyawan yang bekerja di perusahaan tersebut, pengalaman kerja adalah sebagai suatu ukuran tentang lama waktu atau masa kerjanya yang telah ditempuh seseorang dalam memahami tugas-tugas suatu pekerjaan dan telah melaksanakannya dengan baik (Foster, 2011) dan hasil penelitian Situmeang (2017) menyatakan nahwa pengalaman kerja berpengaruh positif dan signifikan terhadap kinerja karyawan.

PT. Astra Majapahit Semarang merupakan perusahaan layanan purna jual terbaik motor Honda dengan jaringan dealer dan bengkel yang tersebar diseluruh wilayah Indonesia.Salah satu kantornya berada di Jl. Majapahit 181 Gayamsari, Semarang. Kantor ini melayani pelanggan Astra motor untuk pembelian motor Honda baik jenis motor matik, bebek, Honda sport. Dealer ini juga melayani perawatan motor Honda seperti pembelian suku cadang (spare parts), ganti oli, apparel dan accessories motor Honda, namun menurut kepala penjualan sepeda motor merek Honda, penjualan dua tahun terakhir tidak mampu mencapai target sehingga mengindikasikan adanya permasalahan dengan kinerja karyawan marketing PT. Astra Majapahit Semarang, berikut adalah pencapaian 
karyawan marketing PT. Astra Majapahit Semarang.

Tabel 1. Realisasi Penjualan Sepeda Motor Honda (All Varians) PT. Astra Majapahit Semarang Tahun 2017 - 2018

\begin{tabular}{|c|c|c|c|c|}
\hline Bulan & $\begin{array}{c}\text { Target } \\
2017 \\
\text { (Unit) } \\
\end{array}$ & $\begin{array}{c}\text { Realisasi } \\
2017 \\
\text { (Unit) }\end{array}$ & $\begin{array}{c}\text { Target } \\
2018 \\
\text { (Unit) }\end{array}$ & $\begin{array}{c}\text { Realisasi } \\
2018 \\
\text { (Unit) } \\
\end{array}$ \\
\hline Januari & 1440 & 1398 & 1764 & 1507 \\
\hline Februari & 1440 & 1273 & 1764 & 1549 \\
\hline Maret & 1440 & 1357 & 1764 & 1640 \\
\hline April & 1440 & 1384 & 1764 & 1653 \\
\hline Mei & 1440 & 1395 & 1764 & 1699 \\
\hline Juni & 1440 & 1342 & 1764 & 1854 \\
\hline Juli & 1440 & 1286 & 1764 & 1726 \\
\hline Agustus & 1440 & 1307 & 1764 & 1747 \\
\hline September & 1440 & 1288 & 1764 & 1693 \\
\hline Oktober & 1440 & 1253 & 1764 & 1660 \\
\hline November & 1440 & 1299 & 1764 & 1749 \\
\hline Desember & 1440 & 1308 & 1764 & 1702 \\
\hline
\end{tabular}

Tabel 1 menunjukkan realisasi penjualan karyawan marketing PT. Astra Majapahit Semarang tidak mampu mencapai target yang telah ditetapkan. Banyak faktor yang mempengaruhi penurunan kinerja karyawan PT. Astra Majapahit Semarang tersebutdan inilah yang menjadi permasalahan penelitian in. Adapun tujuan penelitiannya untuk menganalisis pengaruh etos kerja, keterampilan, kompetensi dan komunikasi terhadap terhadap kinerja karyawan telemarketing Bank Sinar Mas Cabang Semarang.

Amstrong (2012) menyatakan kinerja adalah tentang melakukan pekerjaan dan hasil yang dicapai dari pekerjaan tersebut. Kinerja merupakan hasil pekerjaan yang mempunyai hubungan kuat dengan tujuan strategis organisasi, kepuasan dan memberikan kontribusi ekonomi. John (2010) menyatakan kinerja adalah pelaksanaan fungsi-fungsi yang dituntunt dari seseorang atau suatu perbuatan, suatu prestasi, suatu pameran umum keterampilan.

Kinerja merupakan suatu kondisi yang harus dketahui yang harus dikonfirmasikan kepada pihak tertentu untuk mengetahui tingkat pencapaan hasil suatu instansi dihubungkan dengan sutu visi dan diemban suatu organisasi atau perusahaan yang serta mengetahui dampak positif dan negatif dari suatu kebijakan operasional (Robbins, 2010). Konsep kinerja banyak menghiasi kajian dan praktek dibidang manajemen, sebagai salah satu konsep vital yang menentukan gerak dan perkembangan dari manajemen tertentu. Gibson (2011) menyatakan ada tiga faktor yang mempengaruhi kinerja seseorang yaitu: (1) Faktor individu merupakan kemampuan, keterampilan, latar belakang keluarga, pengalaman tingkat sosial dan demografi seseorang. (2) Faktor psikologis merupakan persefsi, sikap, kepribadian, peran, mtivasi dan kepuasan kerja. (3) Faktor organisasi merupakan struktur organisasi, desain pekerjaan, kepemimpinan, sistem imbalan (reward sistem).

Jika faktor yang mempengaruhi kinerja tersebut dapat dikondisikan dengan baik, maka otomatis kinerja seseorang juga akan semakin meningkat. Dengan demikian tugas manajer ataupun pihak manajer secara umum adalah membuat faktor yang menjunjung keberadaan kinerja tersebut dapat terpenuhi dalam sebuah organisasi ataupun perusahaan.Tujuan tersebut dapat menyangkut berbagai aspek.

Aspek yang pertama menyangkut pasar perusahaan, aspek yang kedua menyangkut keinginan untuk mencapai posisi keuangan tertentu, aspek yang ketiga menyangkut lingkungan dalam organisasi. Oleh karena itu, perlu adanya catatan tertulis terkait tujuan perusahaan yang akan dicapai oleh manajer dan karyawan. Manajer dan karyawan juga harus sepakat dalam pembuatan tujuan tersebut. Tujuan yang jelas akan membuat manajer dan karyawan bekerja secara teratur dan bersemangat untuk mencapai tujuan tersebut.

Perencanaan manajer dan karyawan dalam setahun mendatang meliputi kegiatan yang menyangkut dengan pencapaian tujuan perusahaan. Hasil yang maksimal dari tujuan perusahaan dipengaruhi oleh produktivitas dari karyawannya. Oleh karena itu, sebelum bekerja untuk mencapai tujuan perusahaan perlu diadakan perbaikan kinerja untuk memperbaiki produktivitas kinerja karyawan. Indikator kinerja karyawan menurut Taroreh (2015) yaitu : kedisiplinan, kreativitas, kerjasama, ketelitian dan tanggung jawab.

Etos kerja adalah sikap yang muncul atas kehendak dan kesadaran sendiri yang didasari oleh sistem orientasi nilai budaya terhadap kerja (Sukardewi, 2013). Etos dibentuk oleh berbagai kebiasaan, pengaruh 
budaya, serta sistem nilai yang diyakininya (Tasmara, 2015). Tasmara (2015) menyatakan beberapa faktor-faktor yang mempengaruhi etos kerja, yakni: (1) Agama, dimana pada dasarnya agama adalah suatu sistem nilai yang akan mempengaruhi atau menentukan pola hidup para penganutnya. Cara berpikir, bersikap dan bertindak seseorang tentu diwarnai oleh ajaran agama yang dianut apabila seseorang tersebut sungguh-sungguh dalam kehidupan beragama. (2) Budaya, yaitu sikap mental, tekad, disiplin, dan semangat kerja masyarakat disebut juga sebagai etos budaya dan secara operasional etos budaya ini juga disebut sebagai etos kerja. (3) Kualitas etos kerja tersebut ditentukan oleh sistem orientasi nilai budaya masyarakat yang bersangkutan. (4) Sosial politik yaitu tinggi rendahnya etos kerja suatu masyarakat dipengaruhi oleh ada atau tidaknya struktur politik yang mendorong masyarakat untuk bekerja keras dan bisa menikmati hasil kerja keras dengan penuh. (5) Kondisi Lingkungan yaitu lingkungan alam yang mendukung mempengaruhi manusia yang berada didalamnya melakukan usaha guna bisa mengelola dan mengambil manfaat, dan bahkan bisa mengundang pendatang untuk turut mencari penghidupan dilingkungan tersebut. (6) Pendidikan yaitu etos kerja tidak dapat dipisahkan dengan kualitas sumber daya manusia. Peningkatan sumber daya manusia akan membuat seseorang mempunyai etos kerja keras.

Tasmara (2015) menyatakan beberapa ciri-ciri etos kerja, yaitu: (1) Kecanduan terhadap waktu dimana salah satu esensi dan hakikat dari etos kerja yaitu cara seseorang menghayati, memahami, dan merasakan betapa berharganya waktu. (2) Memiliki moralitas yang bersih (Ikhlas) yaitu salah satu kompetensi moral yang dimiliki oleh seorang yang berbudaya kerja ialah nilai keihklasan. Sebab ikhlas adalah bentuk dari cinta, bentuk kasih sayang dan pelayanan tanpa ikatan. (3) Memiliki Kejujuran karena kejujuran tidak datang dari luar, akan tetapi bisikan dari kalbu yang terus menerus mengetuk dan membisikkan nilai moral yang luhur. (4) Memiliki komitmen merupakan keyakinan yang mengikat sedemikian kukuhnya sehingga terbelenggu seluruh hati nuraninya dan kemudian menggerakkan perilaku menuju arah tertentu yang diyakininya. Dalam komitmen tergantung sebuah tekad, keyakinan, yang melahirkan bentuk vitalitas yang penuh gairah. (5) Konsisten merupakan suatu kemampuan untuk bersikap taat asas, pantang menyerah, dan mampu mempertahankan prinsip walau harus berhadapan dengan resiko yang membahayakan dirinya. Indikator etos kerja menurut Samosir (2016) yaitu: ketulusan, integritas, semangat, kreatif, kecintaan dan kerendahan hati.

Insentif sebagai sarana motivasi yang mendorong para pegawai untuk bekerja dengan kemampuan yang optimal, yang dimaksudkan sebagai pendapatan ekstra di luar gaji atau upah yang telah ditentukan (Robbins, 2012). Pemberian insentif dimaksudkan agar dapat memenuhi kebutuhan para pegawai dan keluarga mereka.Istilah sistem insentif pada umumnya digunakan untuk menggambarkan rencana-rencana pembayaran upah yang dikaitkan secara langsung atau tidak langsung dengan berbagai standar kinerja pegawai atau profitabilitas organisasi.

Menurut Hasibuan (2012) mengemukakan bahwa insentif adalah tambahan balas jasa yang diberikan kepada karyawan tertentu yang prestasinya di atas prestasi standar. Mangkunegara (2012) mengemukakan bahwa insentif adalah suatu bentuk motivasi yang dinyatakan dalam bentuk uang atas dasar kinerja yang tinggi dan juga merupakan rasa pengakuan dari pihak organisasi terhadap kinerja karyawan dan kontribusi terhadap organisasi (perusahaan). Pangabean (2010) mengemukakan bahwa insentif merupakan imbalan langsung yang dibayarkan kepada karyawan karena prestasi melebihi standar yang ditentukan. Dengan mengasumsikan bahwa uang dapat mendorong karyawan bekerja lebih giat lagi, maka mereka yang produktif lebih menyukai gajinya dibayarkan berdasarkan hasil kerja.

Dimana pada prinsipnya pemberian insentif menguntungkan kedua belah pihak.Perusahaan mengharapkan adanya kekuatan atau semangat yang timbul dalam diri penerima insentif yang mendorong mereka untuk bekerja dengan lebih baik dalam arti lebih produktif agar tujuan yang ingin dicapai oleh perusahaan atau instansi 
dapat terpenuhi sedangkan bagi pegawai sebagai salah satu alat pemuas kebutuhannya. Mangkunegara (2012) menyatakan tujuan pemberian insentif adalah untuk memenuhi kepentingan berbagai pihak, yaitu: (1) Mempertahankan tenaga kerja yang terampil dan cakap agar loyalitasnya tinggi terhadap perusahaan. (2) Mempertahankan dan meningkatkan moral kerja pegawai yang ditunjukkan akan menurunnya tingkat perputaran tenaga kerja dan absensi. (3) Meningkatkan produktivitas perusahaan yang berarti hasil produksi bertambah untuk setiap unit per satuan waktu dan penjualan yang meningkat. (4) Meningkatkan standar kehidupannya dengan diterimanya pembayaran di luar gaji pokok. (5) Meningkatkan semangat kerja pegawai sehingga mendorong mereka untuk berprestasi lebih baik.

Pemberian insentif terutama insentif material dimaksudkan agar kebutuhan materi pegawai terpenuhi, dengan terpenuhinya kebutuhan materi itu diharapkan pegawai dapat bekerja lebih baik, cepat dan sesuai dengan standar perusahaan sehingga output yang dihasilkan dapat meningkat daripada input dan akhirnya kinerja pegawai dapat meningkat. Jadi pemberian insentif merupakan sarana motivasi yang dapat merangsang ataupun mendorong pegawai agar dalam diri mereka timbul semangat yang lebih besar untuk berprestasi bagi peningkatan kinerja. Jenisjenis insentif dalam suatu perusahaan atau instansi, harus dituangkan secara jelas sehingga dapat diketahui oleh pegawai dan oleh perusahaan tersebut dapat dijadikan kontribusi yang baik untuk dapat menambah gairah kerja bagi pegawai yang bersangkutan.

Insentif yang memadai akan mendorong semangat dan gairah kerja pegawai, sehingga pegawai akan terus menjaga dan meningkatkan hasil kerjanya ada akhirnya akan meningkatkan keuntungan itu sendiri dalam mencapai tujuan dan sasaran yang ditetapkan, sehingga instansi dan pegawai diharapkan lebih solid dalam membangun kebersamaan menuju kemajuan perusahaan atau instansi. Pedoman penyusunan rencana insentif oleh Dessler (2012) antara lain: (1) Insentif dapat memotivasi pegawai jika mereka melihat adanya kaitan antara upaya yang mereka lakukan dengan pendapatan yang disediakan, oleh karena itu program insentif hendaklah menyediakan ganjaran kepada pegawai dalam proporsi yang sesuai dengan peningkatan kinerja mereka. Pegawai harus berpandangan bahwa mereka dapat melakukan tugas yang diperlukan sehingga standar yang ditetapkan dapat tercapai; (2) Rencana yang dapat dipahami dan mudah di kalkulasi oleh pegawai, para pegawai diharapkan dapat mudah menghitung pendapatan yang bakal diterima dalam berbagai level upaya dengan melihat kaitan antara upaya dengan pendapatan. Oleh karena itu program tersebut sebaiknya dapat dimengerti dan mudah di kalkulasi; (3) Tetapkanlah standar yang efektif dimana standar yang mendasari pemberian insentif ini sebaiknya efektif, di mana standar dipandang sebagai hal yang wajar oleh pegawai. Standar sebaiknya ditetapkan cukup masuk akal, sehingga dalam upaya mencapainya terdapat kesempatan berhasil 50-50 dan tujuan yang akan dicapai hendaknya spesifik, artinya tujuan secara terperinci dan dapat diukur karena hak ini dipandang lebih efektif; (4) Jaminan standar para pegawai sering curiga bahwa upaya yang melampaui standar akan mengakibatkan makin tingginya standar untuk melindungi kepentingan jangka panjang, maka mereka tidak berprestasi di atas standar sehingga mengakibatkan program insentif gagal. Oleh karena itu penting bagi pihak manajemen untuk memandang standar sebagai suatu kontrak dengan pegawai anda begitu rencana itu operasional; (5) Jaminan suatu tarif pokok per jam terutama bagi pegawai pabrik, pihak perusahaan disarankan untuk menjamin adanya upah pokok bagi pegawai, baik dalam per jam, hari, bulan dan sebagainya agar mereka tahu bahwa apapun yang terjadi mereka akan memperoleh suatu upah minimum yang terjamin. Indikator insentif menurut Fath (2016), yaitu: bonus, fasilitas, pujian dan penghargaan

Komunikasi mencakup hampir keseluruhan aspek dalam kehidupan. Terutama dalam praktik keseharian sosial masyarakat yang memiliki bentuk dan kehidupan organisasi, dimana terdapat berbagai unsur komunikasi yang terjadi di dalamnya.Komunikasi dan organisasi memang terdiri dari dua konsep, namun bisa dibilang keduanya sudah saling terkait satu 
sama lain dan tidak bisa untuk dipisahkan. Komunikasi memegang peranan penting dalam suatu organisasi dimana merupakan suatu proses sekaligus sarana untuk saling berbagi informasi antara para anggota atau pihak yang berada dalam organisasi (Robbins, 2012).

Informasi ini yang kemudian digunakan untuk menyamakan pandangan para anggota, menentukan tujuan, hingga memutuskan suatu pilihan yang harus diambil oleh organisasi tersebut. Selain dengan cara berkomunikasi pada umumnya, dalam organisasi pun terdapat cara khusus untuk berkomunikasi seperti menggunakan memo atau catatan kecil, surat menyurat, peraturan dan kebijakan yang ditentukan, hingga jumpa pers dengan publik (Robbins, 2012).

Terdapat dua dimensi yang ada dalam komunikasi organisasi yang mana dibedakan dari segi khalayak atau pihak terkait yang berkomunikasi di dalamnya. Dimensi pertama adalah komunikasi eksternal, yang mana sesuai namanya komunikasi ini terkait antara pihak organisasi dengan pihak luar atau eksternal dari organisasi seperti organisasi lain atau publik (Robbins, 2012). Komunikasi eksternal bisa dilakukan dengan cara komunikasi secara langsung seperti dialog dengan organisasi lain, maupun melalui media massa. Media massa memang masih menjadi sarana dalam menyampaikan komunikasi organisasi kepada pihak eksternal, terutama publik secara umum, karena cakupannya yang luas (Robbins, 2012), sedangkan untuk dimensi yang kedua adalah komunikasi internal, dimana proses komunikasi dilakukan dan terjadi antara pihak atau anggota dalam organisasi tersebut. Komunikasi internal secara sederhana adalah komunikasi yang terjadi dan dilakukan oleh para pihak internal atau anggota dalam organisasi baik yang dilakukan secara formal maupun nonformal (Robbins, 2012). Komunikasi internal dalam suatu organisasi memang sedikit berbeda dengan komunikasi sehari-hari yang kita lakukan, dimana lebih banyak aspek komunikasi formal dan tertulis yang diterapkan.

Robbins (2012) menyatakan ada fungsi komunikasi secara umum: (1) Fungsi komunikasi yang pertama adalah sebagai alat kendali atau kontrol. Dalam hal ini alat kendali berarti dengan komunikasi maka perilaku individu dapat dikontrol dengan penyampaian aturan yang harus dipatuhi. (2) Komunikasi yang baik dan persuasif dapat meningkatkan motivasi seseorang dalam melakukan sesuatu. Menyampaikan informasi yang dapat diraih dalam kehidupan akan membangun motivasi seseorang. (3) Berbagai perasaan yang ada di dalam diri seseorang dapat diungkapkan kepada orang lain dengan cara berkomunikasi. Emosi ini bisa persaan senang, marah, kecewa, gembira, dan lainlain. (4) Dengan berkomunikasi maka kita dapat memberikan informasi yang dibutuhkan oleh orang lain atau kelompok sehingga dengan informasi itu maka proses pengambilan keputusan dapat dilakukan dengan baik. Indikator komunikasi menurut Taroreh (2015) yaitu: pemahaman, kesenangan, pengaruh pada sikap. hubungan yang makin baik dan tindakan

Pengertian pengalaman kerja adalah sebagai suatu ukuran tentang lama waktu atau masa kerjanya yang telah ditempuh seseorang dalam memahami tugas-tugas suatu pekerjaan dan telah melaksanakannya dengan baik (Foster, 2011). Pendapat lain menyatakan bahwa pengertian pengalaman kerja adalah lamanya seseorang melaksanakan frekuensi dan jenis tugas sesuai dengan kemampuannya (Syukur, 2010). Pengalaman kerja adalah proses pembentukan pengetahuan atau ketrampilan tentang metode suatu pekerjaan karena keterlibatan karyawan tersebut dalam pelaksanaan tugas pekerjaan (Manulang, 2012).

Pendapat lain mengenai pengalaman kerja adalah pengetahuan atau keterampilan telah diketahui dan dikuasai seseorang yang akibat dari perbuatan atau pekerjaan yang telah dilakukan selama beberapa waktu tertentu (Trijoko, 2011). Menurut Ranupandojo (2012) mengemukakan pengalaman kerja adalah ukuran tentang lama waktu atau masa kerja yang telah ditempuh seseorang dapat memahami tugas-tugas suatu pekerjaan dan telah melaksanakan dengan baik.

Pengalaman kerja adalah ukuran tentang lama waktu atau masa kerja yang telah ditempuh seseorang dapat memahami tugas-tugas suatu pekerjaan dan telah 
melaksanakan dengan baik Pengalaman kerja adalah pengetahuan atau keterampilan yang telah diketahui dan dikuasai seseorang yang akibat dari perbuatan atau pekerjaan yang telah dilakukan selama beberapa waktu tertentu (Trijoko, 2011).

Mangkunegara (2012) menyatakan pengukuran pengalaman kerja sebagai sarana untuk menganalisa dan mendorong efisiensi dalam pelaksanaan tugas pekerjaan. Beberapa hal yang digunakan untuk mengukur pengalaman kerja seseorang adalah : (1) Gerakannya mantap dan lancar yaitu setiap karyawan yang berpengalaman akan melakukan gerakan yang mantap dalam bekerja tanpa disertai keraguan. (2) Gerakannya berirama artinya terciptanya dari kebiasaan dalam melakukan pekerjaan sehari-hari. (3) Lebih cepat menanggapi tanda-tanda artinya tandatanda seperti akan terjadi kecelakaan kerja. (4) Dapat menduga akan timbulnya kesulitan sehingga lebih siap menghadapinya karena didukung oleh pengalaman kerja dimilikinya maka seorang karyawan yang berpengalaman dapat menduga akan adanya kesulitan dan siap menghadapinya. (5) Bekerja dengan tenang yaitu seorang pegawai yang berpengalaman akan memiliki rasa percaya diri yang cukup besar

Selain itu ada juga beberapa faktor yang mempengaruhi pengalaman kerja karyawan. Beberapa faktor lain mungkin juga berpengaruh dalam kondisi-kondisi tertentu, tetapi adalah tidak mungkin untuk menyatakan secara tepat semua faktor yang dicari dalam diri karyawan potensial. Mangkunegara (2012) menyatakan beberapa faktor tersebut adalah : (1) Latar belakang pribadi, mencakup pendidikan, kursus, latihan, bekerja. Untuk menunjukkan apa yang telah dilakukan seseorang di waktu yang lalu. (2) Bakat dan minat, untuk memperkirakan minat dan kapasitas atau kemampuan seseorang. (3) Sikap dan kebutuhan (attitudes and needs) untuk meramalkan tanggung jawab dan wewenang seseorang. (4) Kemampuan-kemampuan analitis dan manipulatif untuk mempelajari kemampuan penilaian dan penganalisaan. (5) Keterampilan dan kemampuan teknik, untuk menilai kemampuan dalam pelaksanaan aspek-aspek teknik pekerjaan. Indikator pengalaman kerja menurut
Situmeang (2017) yaitu: masa kerja, keterampilan, pengetahuan dan penguasaan

\section{Hubungan Etos Kerja Terhadap Kinerja} Karyawan

Kinerja adalah pelaksanaan fungsi-fungsi yang dituntunt dari seseorang atau suatu perbuatan, suatu prestasi, suatu pameran umum keterampilan.Etos kerja adalah sikap yang muncul atas kehendak dan kesadaran sendiri yang didasari oleh sistem orientasi nilai budaya terhadap kerja (Sukardewi, 2013).

Teori tersebut menyiratkan bahwa etos kerja memiliki pengaruh terhadap kinerja karyawan karena apabila karyawan tidak memiliki etos kerja yang baik maka akan menurunkan kinerja karyawan sebaliknya apabila karyawan memiliki etos kerja yang baik maka akan mampu meningkatkan kinerja yang dimiliki.

Hasil penelitian Samosir (2016) menyatakan bahwa etos kerja berpengaruh positif dan signifikan terhadap kinerja karyawan dan berdasarkan uraian tersebut, maka hipotesis penelitian ini adalah $\mathrm{H} 1$ : etos kerja berpengaruh terhadap kinerja karyawan.

\section{Hubungan Insentif Terhadap Kinerja Karyawan}

John (2010) menyatakan kinerja adalah pelaksanaan fungsi-fungsi yang dituntunt dari seseorang atau suatu perbuatan, suatu prestasi, suatu pameran umum keterampilan sedangkan Insentif sebagai sarana motivasi yang mendorong para pegawai untuk bekerja dengan kemampuan yang optimal, yang dimaksudkan sebagai pendapatan ekstra di luar gaji atau upah yang telah ditentukan (Robbins, 2012).

Teori tersebut menyiratkan bahwa insentif juga memiliki pengaruh terhadap kinerja karyawan karena apabila karyawan tidak mendapatkan insentif yang baik maka akan mampu menurunkan kinerja karyawan sebaliknya apabila karyawan mendapatkan insentif yang baik maka akan mampu meningkatkan kinerja yang dimiliki (John, 2010). Hasil penelitian Fahmifath (2016) menyatakan bahwa insenif berpengaruh positif dan signifikan terhadap kinerja karyawan dan berdasarkan uraian tersebut, maka hipotesis penelitian ini adalah $\mathrm{H} 2$ : 
insentif berpengaruh terhadap kinerja karyawan.

\section{Hubungan Komunikasi Terhadap Kinerja Karyawan}

Kinerja adalah pelaksanaan fungsi-fungsi yang dituntunt dari seseorang atau suatu perbuatan, suatu prestasi, suatu pameran umum keterampilan (John, 2010). Komunikasi memegang peranan penting dalam suatu organisasi dimana merupakan suatu proses sekaligus sarana untuk saling berbagi informasi antara para anggota atau pihak yang berada dalam organisasi (Robbins, 2012). Kedua teori tersebut menyiratkan bahwa komunikasi merupakan salah satu faktor yang mampu mempengaruhi kinerja karyawan karena apabila karyawan tidak mampu berkomunikasi dengan baik maka akan menurunkan kinerja karyawan sebaliknya apabila karyawan mendapatkan komunikasi yang baik maka akan mampu meningkatkan kinerja yang dimiliki.

Hasil penelitian Sumaki dan. Taroreh (2015) menyatakan komunikasi berpengaruh positif dan signifikan terhadap kinerja karyawan. Berdasarkan uraian tersebut, maka hipotesis penelitian ini adalah $\mathrm{H} 3$ : komunikasi berpengaruh terhadap kinerja karyawan.

\section{Hubungan Pengalaman Kerja Terhadap Kineria Karyawan}

John (2010) menyatakan kinerja adalah pelaksanaan fungsi-fungsi yang dituntunt dari seseorang atau suatu perbuatan, suatu prestasi, suatu pameran umum keterampilan sedangkan Pengertian pengalaman kerja adalah sebagai suatu ukuran tentang lama waktu atau masa kerjanya yang telah ditempuh seseorang dalam memahami tugas-tugas suatu pekerjaan dan telah melaksanakannya dengan baik (Foster, 2011).

Teori tersebut menyiratkan bahwa pengalaman kerja berpengaruh terhadap kinerja karyawan karena apabila karyawan menggunakan pengalaman kerja dengan baik maka akan menurunkan kinerja karyawan sebaliknya apabila karyawan menggunakan pengalaman kerja dengan baik maka akan mampu meningkatkan kinerja yang dimiliki.
Hasil penelitian Situmeang (2017) menyatakan bahwa pengalaman kerja berpengaruh positif dan signifikan terhadap kinerja karyawan dan berdasarkan uraian tersebut maka hipotesis penelitian ini adalah $\mathrm{H} 4$ : pengalaman kerja berpengaruh terhadap kinerja karyawan.

\section{METODOLOGI}

Populasi dalam penelitian ini adalah seluruh karyawan telemarketing Bank Sinar Mas Cabang Semarang yang berjumlah 66 karyawan dan sekaligus sebagai sampel (teknik sensus). Alat pengumpul data menggunakan kuesioner. Skala Pengukuran Kuesioner digunakan Skala Likert dengan alternatif jawaban : (1) Sangat Setuju (SS) = 5; (2) Setuju (S)= 4; (3) Kurang Setuju (KS)= 3; (4) Tidak Setuju (TS)= 2; (5) Sangat Tidak Setuju $(S T S)=1$. Adapun uji Instrumennya, yaitu :

1. Uji Validitas (kriteria penilaian, yaitu jika $r$ hitung > $r$ tabel, maka item kuesioner tersebut valid, begitu puka sebaliknya.

2. Uji Reliabilitas (kriteria penilaiannya reliable jika nilai menunjukkan Cronbach alpha > 0,60).

3. Uji Normalitas (kriteria data normal melalui metode uji Kolmogorov Smirnov dimana jika signifikan $>0,05$ ).

4. Uji Multikolonieritas (kriteria tidak terjadi multikolonieritas dalam model regresi yang digunakan melalui nilai Variance Inflation Factor (VIF) diamana VIF < 10).

5. Uji Heteroskedasitas (digunakan uji glejser, dengan kriteria, yaitu jika variabel independen signifikan lebih kecil dari 0,05 maka terjadi heterokedastisitas, begitu pula sebaliknya.

6. Uji t (Parsial), yaitu uji hipotesis digunakan untuk menguji pengaruh variabel independen secara parsial terhadap variabel dependennya dengan syarat apabila nilai signifikan > 0,05 maka secara parsial variabel independen tidak berpengaruh terhadap variabel dependen, begitu pula sebaliknya maka Ho diterima.

7. Uji Ketepatan Model (Uji Statistik F) yaitu apakah model dapat digunakan untuk memprediksi variabel dependen dengan kriteria jika probabilitas (signifikansi) > 0,05 (a) maka Ho diterima sehingga hasilnya tidak tepat. 
8. Koefisien Determinasi $\left(R^{2}\right)$, digunakan untuk mengetahui besar pengaruh variabel independen dalam menerangkan variasi variabel dependen dalam penelitian. Nilai koefisien determinasi antara nol sampai dengan satu. Variabel independen yang hampir semua memberikan informasi yang dibutuhkan dalam memprediksi variasi variabel dependen akan menunjukkan Adjusted $R$ Square atau nilai $R^{2}$ yang mendekati satu.

9. Teknik Analisis Regresi Linier Berganda dengan persamaan : $Y_{\text {kinerja }}$ karyawan $=$ $\begin{array}{lll}b_{1} X_{1 \text { (etos }} \text { kerja) } & +b_{2} X^{+} \\ b_{3} X_{3 \text { (kompetensi) }}+b_{4} X_{4} \text { (komunikasi) } & \end{array}$

\section{HASIL PEMBAHASAN}

Deskripsi Jenis Kelamin Karyawan

Tabel 2 dibawah ini menunjukkan bahwa Bank Sinarmas Cabang Semarang dalam mencari nasabah kartu kredit lebih besar menggunakan tenaga karyawan perempuan karena jenis kelamin perempuan mempunyai tingkat kesabaran dalam menghadapi nasabah.

Tabel 2. Jenis Kelamin Karyawan

\begin{tabular}{clcc} 
No & Jenis kelamin & Jumlah (orang) & $\%$ \\
& & & \\
\hline 1 & Laki-laki & 19 & 28,79 \\
2 & Perempuan & 47 & 71,21 \\
& Jumlah & 66 & 100 \\
\hline
\end{tabular}

Tabel 3. Usia Karyawan

\begin{tabular}{cccc}
\hline No & $\begin{array}{c}\text { Umur } \\
\text { (tahun ) }\end{array}$ & $\begin{array}{c}\text { Jumlah } \\
\text { (orang) }\end{array}$ & $\%$ \\
\hline 1 & $23-24$ & 9 & 13,64 \\
2 & $25-26$ & 14 & 21,21 \\
3 & $27-28$ & 12 & 18,18 \\
4 & $29-30$ & 7 & 10,61 \\
5 & $31-32$ & 10 & 15,15 \\
6 & $33-34$ & 5 & 7,58 \\
7 & $35-36$ & 9 & 13,64 \\
\hline & Jumlah & 66,00 & 100,00 \\
\hline
\end{tabular}

Tabel 3 di atas menunjukkan bahwa karyawan telemarketing Bank Sinarmas Cabang Semarang terbanyak pada usia 2526 tahun. Hal ini menunjukkan Bank Sinarmas Cabang Semarang menginginkan karyawan muda yang memiliki semangat kerja dan motivasi yang tinggi untuk mencapai target.
Tabel 4. Pendidikan Karyawan

\begin{tabular}{cccc} 
No & Pendidikan & Jumlah (orang) & $\%$ \\
\hline 1 & SMA & 13 & 19,70 \\
2 & SMK & 18 & 27,27 \\
3 & D3 & 26 & 39,39 \\
4 & S1 & 9 & 13,64 \\
\hline & Jumlah & 66 & 100 \\
\hline
\end{tabular}

Tabel 4 di atas menunjukkan bahwa pendidikan karyawan telemarketing Bank Sinarmas Cabang Semarang, dalam proses penerimaan karyawan juga memperhatikan faktor pendidikan karena berkaitan dengan target yang dibebankan serta gaya berbicara karyawan tersebut dalam menghadapi nasabah sehingga membebankan karyawan untuk minimal pendidikan adalah D3.

\section{Analisa Deskriptif}

\section{Etos Kerja}

Hasil tanggapan karyawan telemarketing Bank Sinarmas Cabang Semarang terhadap etos kerja menunjukkan bahwa dinilai baik karena rata-rata skor akhir menghasilkan nilai 4,04, namun pada indikator kesedian karyawan melaksanakan pekerjaan mendapatkan jawaban rata-rata skor terendah dibandingkan indikator yang lainnya, hasil tersebut menunjukkan masih ada sebagian karyawan telemarketing Bank Sinarmas Cabang Semarang yang bermalas-malasan dalam bekerja sehingga membuat target tidak tercapai.

\section{Keterampilan \\ Hasil tanggapan karyawan \\ telemarketing Bank Sinarmas Cabang Semarang terhadap keterampilan menunjukkan bahwa keterampilan dinilai baik karena rata-rata skor akhir menghasilkan nilai 3,99, namun pada indikator masa kerja mendapatkan jawaban rata-rata skor terendah dibandingkan indikator yang lainnya. Hasil tersebut} menunjukkan masih ada sebagian karyawan telemarketing Bank Sinarmas Cabang Semarang yang kurang memiliki pengalaman dibidang telemarketing sehingga kurang memiliki masa kerja yang lama dan mempengaruhi target yang telah dibebankan. 


\section{Kompetensi}

Hasil tanggapan karyawan telemarketing Bank Sinarmas Cabang Semarang terhadap kompetensi menunjukkan bahwa kompetensi dinilai baik karena rata-rata skor akhir menghasilkan nilai 3,99 namun pada indikator rasa tanggung jawab mendapatkan jawaban rata-rata skor terendah dibandingkan indikator yang lainnya, hasil tersebut menunjukkan masih ada sebagian karyawan telemarketing Bank Sinarmas Cabang Semarang yang kurang mengedepankan rasa tanggung jawab ketika bekerja sehingga membuat permasalahan timbul dan target yang telah ditetapkan juga tidak tercapai.

\section{Komunikasi}

Hasil tanggapan karyawan telemarketing Bank Sinarmas Cabang Semarang terhadap komunikasi menunjukkan bahwa komunikasi dinilai baik karena rata-rata skor akhir menghasilkan nilai 3,97 namun pada indikator tindakan mendapatkan jawaban rata-rata skor terendah dibandingkan indikator yang lainnya, hasil tersebut menunjukkan masih ada sebagian karyawan telemarketing Bank Sinarmas Cabang Semarang yang hanya mendengarkan arahan yang diberikan pimpinan namun tidak melakukan tindakan atas himbauan tersebut sehingga target yang telah dibebankan tidak mampu tercapai.

\section{Kinerja Karyawan}

Hasil tanggapan karyawan telemarketing Bank Sinarmas Cabang Semarang terhadap kinerja karyawan kinerja karyawan dinilai baik karena rata-rata skor akhir menghasilkan nilai 3,72 namun pada indikator ketetapatan waktu mendapatkan jawaban rata-rata skor terendah dibandingkan indikator yang lainnya, hasil tersebut menunjukkan masih ada sebagian karyawan telemarketing Bank Sinarmas Cabang Semarang dalam mencapai target yang telah ditetapkan tidak mampu selalu tepat waktu.

\section{Hasil Uji Instrumen}

a. Uji Validitas Data

Hasil penelitian menunjukkan $r$ hitung $>r$ tabel dengan demikian semua indikator hasilnya valid.

\section{b. Uji Reliabilitas Data}

Hasil penelitian menunjukkan bahwa semua variabel mempunyai koefisien alpha yang cukup besar yaitu > 0,60, dengan demikian semua indikator hasilnya reliabel.

\section{c. Normalitas}

Hasil Uji Kolmogorov Smirnov memiliki signifikansi sebesar $0.789>0,05$ yang artinya nilai residuals sudah terdistribusi normal.

\section{d. Multikolonieritas}

Hasil uji multikolonieritas, menunjukkan bahwa semua nilai VIF dari variabel bebas memiliki nilai < 10 yang artinya antar variabel independen tidak terjadi korelasi.

\section{e. Heteroskedastisitas}

Hasil uji heteroskedastisitas menunjukkan semua variabel independen mempunyai nilai signifikansi > 0,05. Hasil tersebut menunjukkan tidak terjadi ketidaksamaan variance dari pengamatan satu dengan pengamatan lainnya.

d. Analisis Regresi Linear Berganda

Tabel 5. Hasil uji regresi linier berganda

\begin{tabular}{ll}
\hline Model & $\begin{array}{c}\text { Standardized } \\
\text { coefficients } \\
\text { Beta }\end{array}$ \\
\hline $1 \quad$ (Constant) & .267 \\
$\quad$ Etos kerja & .331 \\
Keterampilan & .297 \\
Kompetensi & .294 \\
Komunikasi &
\end{tabular}

Persamaan hasil penelitiannya, yaitu :

$Y_{\text {(Kinerja karyawan) }}=0,267$ etos kerja $+0,331$ keterampilan $+0,297$ kompetensi $+0,294$ komunikasi Hasil analisa regresi linear berganda dapat dideskripsikan sebagai berikut:

1. Hasil $B_{1}$ etos kerja menunjukkan hasil positif yang berarti apabila etos kerja ditingkatkan maka kinerja karyawan akan semakin meningkat.

2. Hasil $B_{2}$ keterampilan menunjukkan hasil positif yang berarti apabila keterampilan ditingkatkan maka kinerja karyawan akan semakin meningkat.

3. Hasil $B_{3}$ kompetensi menunjukkan hasil positif yang berarti apabila kompetensi 
ditingkatkan maka kinerja karyawan akan semakin meningkat.

4. Hasil $B_{4}$ komunikasi menunjukkan hasil positif yang berarti apabila komunikasi semakin baik maka kinerja karyawan akan semakin meningkat.

f. Uji Hipotesis

Tabel 6. Hasil Uji Hipotesis

\begin{tabular}{lll}
\hline & & \\
Model & $\mathrm{t}$ & \multicolumn{1}{c}{ Sig. } \\
\hline $1 \quad$ (Constant) & -1.793 & .078 \\
Etos kerja & 3.001 & .004 \\
Keterampilan & 3.583 & .001 \\
Kompetensi & 3.375 & .001 \\
Komunikasi & 3.409 & .001 \\
\hline
\end{tabular}

- Etos Kerja Terhadap Kinerja Karyawan : Nilai signifikansi hasil sebesar 0,001 lebih kecil dari 0,05 dimana hasil tersebut menunjukkan bahwa hipotesis 1 dalam penelitian ini diterima, yang artinya bahwa etos kerja berpengaruh signifikan terhadap kinerja karyawan.

- Uji Hipotesis Keterampilan Terhadap Kinerja Karyawan : Nilai signifikansi hasil sebesar 0,001 lebih kecil dari 0,05 dimana hasil tersebut menunjukkan bahwa hipotesis 2 dalam penelitian ini diterima, yang artinya bahwa keterampilan berpengaruh signifikan terhadap kinerja karyawan.

- Uji Hipotesis Kompetensi Terhadap Kinerja Karyawan : Nilai signifikansi hasil sebesar 0,001 lebih kecil dari 0,05 dimana hasil tersebut menunjukkan bahwa hipotesis 3 dalam penelitian ini diterima, yang artinya bahwa kompetensi berpengaruh signifikan terhadap kinerja karyawan.

- Uji Hipotesis Komunikasi Terhadap Kinerja Karyawan: Nilai signifikansi hasil sebesar 0,001 lebih kecil dari 0,05 dimana hasil tersebut menunjukkan bahwa hipotesis 4 dalam penelitian ini diterima, yang artinya bahwa komunikasi berpengaruh signifikan terhadap kinerja karyawan.

\section{g. Uji Ketepatan Model}

Dari hasil uji $F$ tersebut (Tabel 7) diperoleh nilai $F$ adalah sebesar 20.945 dengan tingkat signifikansi $0,000<0,05$. Hal ini menunjukkan bahwa variabel etos kerja, keterampilan, kompetensi dan komunikasi secara tepat untuk menjelaskan variabel kinerja karyawan.

Tabel 7. Uji Ketepatan Model

\begin{tabular}{llcc}
\hline Model & & $\mathrm{F}$ & Sig. \\
\hline 1 & Regression & 20.945 & $.000^{\mathrm{a}}$ \\
& Residual & & \\
& Total & & \\
\hline
\end{tabular}

\section{h. Koefisien Determinasi}

Tabel 8 dibawah ini menunjukkan adjusted $R$-square sebesar 0,551 atau 55,1 $\%$ artinya kinerja karyawan dapat dijelaskan oleh etos kerja, keterampilan, kompetensi dan komunikasi sedangkan sisanya sebesar 0,449 atau $44,9 \%$ dijelaskan oleh variabel lain diluar penelitian ini, seperti : kompensasi, komitmen organisasi, dan lainlain.

Tabel 8. Hasil Uji Koefisien Determinasi

\begin{tabular}{lrr}
\hline Model & Adjusted R Square & $\begin{array}{c}\text { Std. Error of the } \\
\text { Estimate }\end{array}$ \\
\hline 1 & .551 & 2.21337 \\
\hline
\end{tabular}

\section{Pengaruh Etos Kerja Terhadap Kinerja Karyawan}

Hasil penelitian menunjukkan bahwa etos kerja berpengaruh positif dan signifikan terhadap kinerja karyawan yang artinya apabila etos kerja ditingkatkan maka akan mampu meningkatkan kinerja karyawan dan hasil penelitian ini mendukung hasil penelitian dari Hadiansyah dan Yanwar (2015) yang menyatakan etos kerja berpengaruh positif dan signifikan terhadap kinerja karyawan.

\section{Pengaruh Keterampilan Terhadap Kinerja Karyawan}

Hasil penelitian menunjukkan bahwa keterampilan berpengaruh positif dan signifikan terhadap kinerja karyawan yang artinya apabila keterampilan ditingkatkan maka akan mampu meningkatkan kinerja karyawan dan hasil penelitian ini mendukung Suhartini (2016) yang menyatakan keterampilan berpengaruh positif dan signifikan terhadap kinerja karyawan. 


\section{Pengaruh Kompetensi Terhadap Kinerja} Karyawan

Hasil penelitian menunjukkan bahwa kompetensi berpengaruh positif dan signifikan terhadap kinerja karyawan yang artinya apabila kompetensi ditingkatkan maka akan mampu meningkatkan kinerja karyawan dan hasil penelitian ini mendukung Faustyna (2014) yang menyatakan kompetensi berpengaruh positif dan signifikan terhadap kinerja karyawan.

\section{Pengaruh Komunikasi Terhadap Kinerja Karyawan}

Hasil penelitian menunjukkan bahwa komunikasi berpengaruh positif dan signifikan terhadap kinerja karyawan yang artinya apabila komunikasi ditingkatkan maka akan mampu meningkatkan kinerja karyawan dan hasil penelitian ini mendukung Hadiansyah dan Yanwar (2015)) yang menyatakan komunikasi berpengaruh positif dan signifikan terhadap kinerja karyawan.

\section{KESIMPULAN}

1. Etos kerja berpengaruh positif dan signifikan terhadap kinerja karyawan yang berarti apabila etos kerja ditingkatkan maka akan meningkatkan kinerja karyawan.

2. Keterampilan berpengaruh positif dan signifikan terhadap kinerja karyawan yang berarti apabila keterampilan ditingkatkan maka akan meningkatkan kinerja karyawan.

3. Kompetensi berpengaruh positif dan signifikan terhadap kinerja karyawan yang berarti apabila kompetensi ditingkatkan maka akan meningkatkan kinerja karyawan.

4. Komunikasi berpengaruh positif dan signifikan terhadap kinerja karyawan yang berarti apabila komunikasi ditingkatkan maka akan meningkatkan kinerja karyawan.

\section{Saran}

1. Dalam meningkatkan etos kerja pada indikator kesediaan karyawan memiliki skor terendah dibandingkan indikator yang lainnya, disarankan agar Bank Sinarmas Cabang Semarang memberikan kelas motivasi agar karyawan secara sadar untuk bersedia memajukan Bank Sinarmas Cabang Semarang.

2. Dalam meningkatkan ketrampilan pada indikator masa kerja memiliki skor terendah dibandingkan indikator yang lainnya, disarankan agar Bank Sinarmas Cabang Semarang memberikan pelatihan untuk meningkatkan softskill karyawan agar mampu secara cepat mengikuti sistem kerja yang ada di Bank Sinarmas Cabang Semarang.

3. Dalam meningkatkan kompetensi pada indikator rasa tanggung jawab memiliki skor terendah dibandingkan indikator yang lainnya, disarankan agar Bank Sinarmas Cabang Semarang memberikan sistem pengawasan dengan cara pelaporan lisan baik tulisan agar karyawan dapat bertanggung jawab dengan apa yang dikerjakan.

4. Dalam meningkatkan komunikasi pada indikator tindakan jawab memiliki skor terendah dibandingkan indikator yang lainnya, disarankan agar Bank Sinarmas Cabang Semarang memberikan feedback dengan cara karyawan memberikan tanggapan dan laporan ketika telah mendapatkan arahan dari pimpinan Bank Sinarmas Cabang Semarang.

5. Dalam meningkatkan kinerja karyawan pada indikator ketetapatan waktu memiliki skor terendah dibandingkan indikator yang lainnya, disarankan agar Bank Sinarmas Cabang Semarang memberikan konseling apabila masaih ada karyawan yang tidak tepat waktu dalam menyelesaikan target.

\section{DAFTAR PUSTAKA}

Amalia, E. 2015. Pengaruh Motivasi Kerja dan Disiplin Kerja Terhadap Kinerja Karyawan. Jurnal MSDM Vol 1 No 1.

Arsyendra, Y. 2015. Pengaruh Motivasi Kerja dan Disiplin Kerja Terhadap Kinerja Karyawan. Jurnal MSDM. Vol. 5. No. 1.

Faustyna. 2014. Analisis Pengaruh Kompetensi dan Komitmen Pada Tugas Terhadap Kinerja Karyawan. Jurnal IImu Manajemen Dan Bisnis Vol. 3. No. 4.

Ferdinand, A. 2013. Metode Penelitian Manajemen. Semarang: BP. UNDIP. 
Ghozali. I. 2013. Aplikasi Analisis Mulitivariate Dengan Progam IBM SPSS 21. Semarang: BP. UNDIP.

Helmi, A.F. 1996. Disiplin Kerja. Edisi Khusus Ulang Tahun XXXII.

Impiansi, R \& Citra, S. 2016. Analisis Pengaruh Kecerdasan Emosional, Komunikasi dan Lingkungan Kerja Terhadap Kinerja Karyawan. Jurnal Manajemen Sumber Daya Manusia Vol 3. No 5.

Islami, H. 2013. Pengaruh Lingkungan Kerja, Karakteristik Individu dan Motivasi Kerja Terhadap Kinerja Karyawan. Jurnal Manajemen Vol 3. No 2.

Khahar, I.A. 2008. Disiplin Kerja, Kepemimpinan dan Lingkungan Kerja Terhadap Kinerja Karyawan. Jurnal Studi Perpustakaan dan Informasi. Vol 4. No 1.

Khosiah, O. (2014). Pengaruh Rekrutmen dan Pengembangan Karir terhadap Kinerja Karyawan. Jurnal EMBA Vol 4. No 3.

Kusmaningtyas, A. 2015. Pengaruh Budaya Organisasi, Kepuasan Kerja dan Lingkungan Kerja Terhadap Kinerja Karyawan. Jurnal EMBA Vol 2 No 5.

Kusmanto. 2017. Analisis Pengaruh Pengawasan, Motivasi dan Pembagian Kerja Terhadap Kinerja Karyawan. Jurnal Riset Manajemen Vol 3. No 2.

Kusuma, JM. 2014. Pengaruh Insentif, Motivasi Kerja dan Disiplin Kerja Terhadap Kinerja Karyawan. Jurnal EMBA Vol 1. No 4.

Mangkunegara, AP. 2011. Manajemen Sumber Daya Manusia. Yogyakarta: Penerbit. ANDI.

Mangkunegara, A. P. (2013). Manajemen Sumber Daya Manusia. Jakarta: Erlangga.

Mansur. (2017). Analisis Penempatan Kerja dan Stres Kerja Terhadap Kinerja Karyawan. Jurnal IImu Manajemen Vol 4. No 8.
Marpaung, M. 2014. Analisis Disiplin Kerja dan Kompensasi Terhadap Kinerja Karyawan. Jurnal IImiah Widya.Vol 2. No 1.

Maulidiah, V. 2015. Analisis Pengaruh Pelatihan, Pengalaman Kerja dan Promosi Jabatan Terhadap Kinerja Karyawan. Jurnal EMBA Vol 3. No 7.

Musafir. 2013. Analisis Pengaruh Kompensasi Finansial dan Kompensasi Non Finansial Terhadap Kinerja Karyawan. Jurnal Manajemen dan Bisnis. Vol 3. No 8.

Nasution, E. 2014. Analisis Pengaruh Motivasi kerja dan Kepemimpinan Terhadap Kinerja Karyawan. Jurnal Al Bayan Vol 20. No 29.

Panggabean, MS. 2002. Manajemen Sumber Daya Manusia. Bogor: Ghalia Indonesia.

Pujiati. 2015. Pengaruh Budaya Organisasi dan Lingkungan Kerja dan Motivasi Kerja Terhadap Kinerja Karyawan. Jurnal MSDM Vol 3. No 7.

Putra, C.S. 2014. Analisis Pengaruh Kepemimpinan, Budaya Organisasi dan Motivasi Kerja Terhadap Kinerja Karyawan. Jurnal Manajemen Vol 3. No 5.

Robbins, S.P. 2014. Manajemen Sumber Daya Manusia Jilid II. Bandung: Alfabeta.

Robert. 2016. Pengaruh Pengetahuan, Keterampilan dan Kemampuan Karyawan Terhadap Kinerja Karyawan. Jurnal Manajemen. Vol. 3 No. 2.

Rumengan, L.T. 2015. Analisis Kompensasi dan Kepemimpinan Terhadap Kinerja Karyawan. Jurnal EMBA Vol. 3. No. 1 Maret.

Setiawan, A. 2010. Manajemen Sumber Daya Manusia, Alfabeta, Bandung.

Simamora. 2013. Manajemen Sumber Daya Manusia. Bogor: Ghalia Indonesia

Sinanamo. 2011. Manajemen Sumber Daya Manusia. Penerbit Erlangga: Jakarta Indonesia 
Sugiyono. 2012. Metode Penelitian Bisnis. Bandung: Alfabeta Bandung.

Suhartini, Y. 2016. Pengaruh Pengetahuan, Keterampilan dan Kemampuan Karyawan Terhadap Kinerja Karyawan. Jurnal Manajemen. Vol 3. No 2.

Sumaki, W. J. 2015. Analisis Pengaruh Disiplin Kerja, Budaya Organisasi dan Komunikasi Terhadap Kinerja Karyawan. Jurnal EMBA Vol 7. No 4.

Sumaki, W.J., Taroreh, R.N \& Soepono, D. 2015. Pengaruh Disiplin Kerja,
Budaya Organisasi dan Komunikasi Terhadap Kinerja Karyawan. Jurnal Manajemen dan Bisnis. Vol 3. No 3.

Yanmar, A. H \& Purnamasari, R. (2015). Pengaruh Etos Kerja Terhadap Kinerja Karyawan. Jurnal Manajemen dan Bisnis. Vol 3. No 2.

Yasa, I.P.S. 2015. Pengaruh Kompensasi dan Lingkungan Kerja Terhadap Kepuasan Kerja dan Kinerja Karyawan. Jurnal EMBA. Vol 1 No 5. 